\title{
Perception of asthma as a factor in career choice among young adults with asthma
}

\author{
Sacha Bhinder MD HBSc${ }^{1}$, Lisa Cicutto RN PhD ${ }^{1-3}$, Husam M Abdel-Qadir MD ${ }^{1}$, Susan M Tarlo MBBS FRCPC
}

\begin{abstract}
S Bhinder, L Cicutto, HM Abdel-Qadir, SM Tarlo. Perception of asthma as a factor in career choice among young adults with asthma. Can Respir J 2009;16(6):e69-e75.
\end{abstract}

BACKGROUND/AIM: Asthma is a common chronic condition that can be aggravated by workplace exposures. Young adults with asthma should know how their future occupation might affect their asthma, and potentially, their quality of life. The aim of the present study was to assess the awareness of young adults to occupational risks for asthma and high-risk occupations, as well as their perception of the role of asthma in career choice.

METHODS: Young adults 16 to 22 years of age with reported physiciandiagnosed asthma were recruited to complete a questionnaire eliciting information regarding asthma control, career choice and awareness of occupational exposure risks.

RESULTS: A small majority of the study cohort (56.4\%) could identify occupations that cause or exacerbate asthma, and $34.7 \%$ indicated that asthma was an important factor in their career plans. Family physicians were most responsible for asthma management $(80.2 \%)$, but young adults were more likely to discuss asthma and career plans with their parents $(43.6 \%)$ or friends $(29.7 \%)$ than with their family physician $(13.9 \% ; \mathrm{P}<0.001)$.

CONCLUSION: Young adults with asthma have suboptimal awareness of potential work-related asthma risks. Family physicians most commonly provide asthma care to these young adults. However, few young adults are talking to their family physicians about career choices and asthma. This observation represents an area of asthma care that needs to be explored in young adults with asthma.

Key Words: Asthma; Career choice; Occupational asthma; Risk perception; Socioeconomic factors survey; Work-exacerbated asthma; Work-related asthma; Young adults

A sthma is a common chronic condition among young adults, with prevalence rates ranging from $7 \%$ to $13 \%$ in the United States (1), Canada (2) and the United Kingdom (3). Young adults with asthma often continue to be affected through adulthood, and exacerbations may lead to limitations in quality of life, missed days of school and work, decreased productivity or hospitalization. While asthma is not curable, it can be controlled with appropriate management, and acceptable control can allow patients to have a higher quality of life than they would have otherwise (4).

Young adults present unique obstacles to effective asthma care. Young adults are at greater risk of denying symptoms, being careless about dangerous inhalation exposure and potentially self-medicating erratically (5). To optimize self-care, maximize symptom control and minimize exposures to agents that can exacerbate asthma, asthma health care providers should establish strong relationships with young adults with asthma and their families, and understand their needs and perspectives toward asthma (6).

An appreciation of the importance of occupational asthma has increased over the past two decades (7) and, more recently,

\section{La perception de l'asthme comme facteur de choix de carrière chez les jeunes adultes asthmatiques}

HISTORIQUE ET OBJECTIF : L'asthme est une maladie chronique courante qui peut s'aggraver par l'exposition en milieu de travail. Les jeunes adultes asthmatiques devraient connaître l'incidence de leur future carrière sur leur asthme et, peut-être, leur qualité de vie. La présente étude visait à évaluer la sensibilisation des jeunes adultes aux risques professionnels de l'asthme et aux emplois à haut risque, ainsi que leur perception du rôle de l'asthme dans leur choix de carrière.

MÉTHODOLOGIE : On a recruté des jeunes adultes de 16 à 22 ans atteints d'asthme diagnostiqué par au médecin pour qu'ils remplissent un questionnaire visant à obtenir de l'information sur le contrôle de l'asthme, le choix de carrière et la sensibilisation aux risques d'exposition professionnelle.

RÉSULTATS : Une petite majorité de la cohorte à l'étude (56,4\%) pouvait nommer des carrières qui provoquent ou exacerbent l'asthme, et $34,7 \%$ ont affirmé que l'asthme était un facteur important dans leur plan de carrière. Les médecins de famille étaient les plus responsables de la prise en charge de l'asthme (80,2\%), mais les jeunes adultes étaient plus susceptibles de parler de leur asthme et de leur plan de carrière avec leurs parents $(43,6 \%)$ ou leurs amis $(29,7 \%)$ qu'avec leur médecin de famille $(13,9 \% ; \mathrm{P}<0,001)$.

CONCLUSION : La sensibilisation des jeunes adultes asthmatiques envers les risques professionnels potentiels liés à l'asthme est sous-optimale. Le plus souvent, ce sont des médecins de famille qui dispensent des soins à ces jeunes adultes. Cependant, peu de jeunes adultes parlent à leur médecin de famille de leur choix de carrière lié à l'asthme. Ces observations représentent un domaine de l'asthme qu'il faut explorer chez les jeunes adultes asthmatiques.

the frequency of work-exacerbated asthma (WEA) has been recognized (8). The term 'work-related asthma' (WRA) is used to encompass both occupational asthma and WEA. It may be beneficial to advise and inform young adults with asthma about WRA to assist them in selecting a suitable career before starting their training (9), although we have not identified any prospective studies that have assessed this.

Adolescence and young adulthood represent a time in life when career choices are beginning to take shape. Young adults with asthma should be aware that there is a risk of asthma worsening by exposure to workplace respiratory irritant agents and that new immunological sensitization to workplace agents may develop that might necessitate long-term alterations in medical management (10) and/or workplace changes. A Swedish study (11) demonstrated that working-aged men who had asthma as adolescents tended to avoid jobs with a higher probability of exposures known to cause airway irritation compared with nonasthmatic controls. Individuals with adolescent asthma also had greater morbidity and mortality than healthy individuals or those with allergic rhinitis. Currently, little is known about the role of asthma in the career aspirations of

\footnotetext{
${ }^{1}$ Faculty of Medicine; ${ }^{2}$ Lawrence Bloomberg Faculty of Nursing, University of Toronto, Toronto, Ontario; ${ }^{3}$ National Jewish Health, Denver, Colorado, USA

Correspondence and reprints: Dr Susan M Tarlo, University Health Network, Toronto Western Hospital, 399 Bathurst Street, East Wing 7-449,

Toronto, Ontario, M5T 2S8. Telephone 416-603-5177, fax 416-603-6763, e-mail susan.tarlo@utoronto.ca
} 
young adults $(12,13)$. Such information may be useful in the future development of an educational tool for this group of asthmatic patients.

As a result, a survey of young adults with asthma was conducted to understand the role of socioeconomic and demographic factors, and asthma in future career planning. The primary objective was to determine how asthma affects the career aspirations of adolescents and young adults with asthma. Other aspects investigated were whether the presence of poorly controlled asthma limited career aspirations, and to identify their knowledge and risk perceptions of jobs associated with increased risk of WRA.

\section{METHODS}

\section{Study design}

A cross-sectional postal survey was conducted from May 2006 to August 2007, using a modified Dillman's protocol (14). Ethics approval was obtained from the University of Toronto Health Sciences II Research Ethics Board (Toronto, Ontario). Participants were recruited through paper flyers posted within universities, colleges, community centres, hospital asthma clinics and community medical clinics. Interested participants contacted the study team by telephone or e-mail to obtain additional information. Eligible participants were mailed a package containing general information about the study, an informed consent form, the questionnaire and a preaddressed postage-paid envelope. Eligibility criteria included a self-report of physician-diagnosed asthma and being between 16 and 22 years of age.

\section{Questionnaire}

The questionnaire (Appendix A) was developed for the study and was based on existing literature and instruments $(15,16)$. Areas assessed included asthma management, symptom experience, career choices, and demographic and socioeconomic information. The questionnaire consisted of four main sections, was only available in English and required $10 \mathrm{~min}$ to $15 \mathrm{~min}$ to complete.

Asthma variables: Asthma history and management-related variables included identification of asthma care providers, allergies, rhinitis and/or eczema, asthma triggers, smoking history, medication use and the perceived impact of asthma on daily life. Asthma control variables were based on Canadian asthma practice guidelines (15) and included frequency of weekly nocturnal awakening due to asthma, asthma symptoms, activity limitation related to asthma and short-acting bronchodilator use. Occupational specific variables included knowledge of occupations that can aggravate asthma, the need to use protective workplace equipment when appropriate and the importance of recognizing the impact of asthma in future career choices. Participants were allowed to select a maximum of three nonprioritized future career choices. Participants were also asked whether they had spoken to their family physician, parents, counsellors or friends about asthma with regard to their future career choices.

Sociodemographic variables: Sociodemographic variables included age, sex, educational level, current employment and parental employment. Parental employment and job title were elicited for both parents separately. Categorization of current and future participant occupations and present parental occupational rank was determined using the Hollingshead Index (17), which was modified to exclude education from the occupational score because parental education data were not elicited from participants $(18,19)$. The occupation score was coded from 1 to 8 , with a score of 1 corresponding to a highranked occupation (ie, high executive or professional) and a score of 8 corresponding to a low-ranked occupation (ie, unemployed or homemaker) (19). Average home income was determined by participant's postal codes and Statistics Canada average household income data by Forward Sortation Area postal codes (20). Average household income was categorized into four categories: less than $\$ 60,000$, between $\$ 60,001$ and $\$ 75,000$, between $\$ 75,001$ and $\$ 90,000$, and greater than $\$ 90,000$ per year.

\section{Statistical analysis}

Data from returned questionnaires were entered and stored in a secure database (SPSS, version 15.0.0, SPSS Inc, USA). All variables were explored using descriptive statistics. Statistical analysis involving parental Hollingshead occupational rankings studied two separate cohorts: one composed of parents with a higher rank compared with their spouse and a second composed of spouses with a lower score. Inferential analysis of demographic variables was performed using ANOVA, while ranked occupational data were analyzed by Mann-Whitney type rank tests. Significant demographic variables identified from the ANOVA were introduced stepwise into logistic regression analysis to identify independent predictors of occupational specific variables. All inferential tests were two-sided and statistical significance was accepted at $\mathrm{P}<0.05$.

\section{RESULTS}

A total of 111 individuals contacted the study team for additional information about the study. All respondents indicated a desire to participate and were subsequently mailed questionnaire packages. In total, 103 of the 111 questionnaires were returned, representing a response rate of (93\%). However, two questionnaires were excluded from analysis because the respondents exceeded the inclusion age (54 and 24 years of age), leaving 101 questionnaires included in the analyses.

Demographic characteristics of the participants are presented in Table 1. Most participants were employed, nonsmokers, older than 18 years of age $(82.1 \%)$ and enrolled in a postsecondary institution (70.3\%). An even distribution of participants was observed across sex, number of years with asthma and average home income quartiles.

Approximately one-half of the participants indicated that asthma does not impact their lives (44.6\%), and most indicated that asthma was not an important factor in their career plans (65.3\%). However, subjects who indicated that asthma affects their life were more likely to indicate that asthma played an important role in their career plans $(\mathrm{P}<0.001)$. Approximately one-half of the participants (53.5\%) recognized the importance of wearing protective equipment in the workplace when appropriate.

Occupational categorization was completed for participant's current and future occupation and current parental occupation according to the Hollingshead method (Table 2). In total, 97 participants provided at least one future career choice, 94 provided at least two and 81 provided the maximum 
TABLE 1

Sociodemographic characteristics $(n=101)$

\begin{tabular}{lc}
\hline Characteristic & $\mathbf{n}(\%)$ \\
\hline Age, years & \\
$16-17$ & $18(17.8)$ \\
$18-19$ & $36(35.6)$ \\
$20-22$ & $47(46.5)$ \\
Age, years (mean \pm SD) & $19.21 \pm 1.89$ \\
Female sex & $54(53.5)$ \\
Years with asthma & \\
$\leq 5$ & $21(20.8)$ \\
$6-10$ & $33(32.7)$ \\
$11-15$ & $23(22.8)$ \\
$16-20$ & $21(20.8)$ \\
$>20$ & $3(3.0)$ \\
Years with asthma (mean \pm SD) & $10.53 \pm 5.57$ \\
Current enrollment in educational program & \\
High school & $20(19.8)$ \\
College & $10(9.9)$ \\
University & $61(60.4)$ \\
None & $10(9.9)$ \\
Mean home income & \\
$<\$ 60,000$ & $20(19.8)$ \\
$\$ 60,001$ to $\$ 75,000$ & $29(28.7)$ \\
$\$ 75,001$ to $\$ 90,000$ & $26(25.7)$ \\
$>\$ 90,000$ & $26(25.7)$ \\
Currently employed & $59(58.4)$ \\
Current smoker & $10(9.9)$ \\
\hline
\end{tabular}

TABLE 2

Hollingshead data for jobs

\begin{tabular}{|c|c|c|c|c|}
\hline \multirow[b]{2}{*}{$\begin{array}{l}\text { Hollingshead } \\
\text { rank score }\end{array}$} & \multirow{2}{*}{$\begin{array}{l}\text { Hollingshead } \\
\text { occupational } \\
\text { description }\end{array}$} & \multicolumn{3}{|c|}{ Occupation, n (\%) } \\
\hline & & $\begin{array}{l}\text { Participant } \\
\text { present* }^{*}\end{array}$ & Parental & $\begin{array}{c}\text { Participant } \\
\text { desired }^{\dagger}\end{array}$ \\
\hline 1 & $\begin{array}{l}\text { Higher executive, } \\
\text { major profes- } \\
\text { sional, etc }\end{array}$ & $0(0.0)$ & $41(20.3)$ & $151(55.5)$ \\
\hline 2 & $\begin{array}{l}\text { Business } \\
\text { manager, etc }\end{array}$ & $8(7.9)$ & $24(11.9)$ & $31(11.4)$ \\
\hline 3 & $\begin{array}{l}\text { Administrative per- } \\
\text { sonnel, etc }\end{array}$ & $7(6.9)$ & $21(10.4)$ & $33(12.1)$ \\
\hline 4 & $\begin{array}{l}\text { Clerical and sales, } \\
\text { technician, etc }\end{array}$ & $34(33.6)$ & $28(13.9)$ & $14(5.1)$ \\
\hline 5 & Skilled manual & $8(7.9)$ & $18(8.9)$ & $39(14.3)$ \\
\hline 6 & $\begin{array}{l}\text { Machine operators, } \\
\text { semiskilled labour, } \\
\text { etc }\end{array}$ & $2(2.0)$ & $8(4.0)$ & $4(1.5)$ \\
\hline 7 & Unskilled labour & $0(0.0)$ & $21(10.4)$ & $0(0.0)$ \\
\hline 8 & $\begin{array}{l}\text { Unemployed, } \\
\text { homemaker }\end{array}$ & $42(41.6)$ & $41(20.3)$ & $0(0.0)$ \\
\hline
\end{tabular}

*Participants' present occupation included part-time work and did not include student status; ${ }^{\dagger}$ Desired future occupations included one or more choices for each participant. Data adapted from references 17-19

of three choices. Participants were primarily currently employed in clerical, sales or skilled manual occupations $(71.2 \%)$. This included participants who worked part-time while attending postsecondary education and intended to pursue a career path toward a professional, executive or business manager type career $(66.9 \%)$. Participants $(82.1 \%)$ frequently selected future occupations that exceeded their parental occupational rank $(\mathrm{P}<0.001)$. Participants desiring a higher occupational rank in
TABLE 3

Asthma management and control-related variables

\begin{tabular}{lc}
\hline Variable & $\mathbf{n}(\%)$ \\
\hline Asthma care provider* & \\
Family physician & $81(80.2)$ \\
Walk-in clinic & $11(10.9)$ \\
Pediatrician & $9(8.9)$ \\
Allergist & $8(7.9)$ \\
Respirologist & $6(5.9)$ \\
Not using medication & $18(17.8)$ \\
Medication use* & \\
Short-acting bronchodilator & $67(66.3)$ \\
Inhaled steroid & $40(39.6)$ \\
Combination (LABA + inhaled steroid) & $25(24.8)$ \\
Antileukotriene & $12(11.9)$ \\
Long-acting bronchodilator & $5(5.0)$ \\
Oral steroid & $4(4.0)$ \\
Ever visit the emergency room due to asthma & $39(38.6)$ \\
Ever hospitalized due to asthma & $27(26.7)$ \\
\hline
\end{tabular}

${ }^{*}$ Question asked participants to check all that apply; therefore, sum may not equal 100\%. LABA Long-acting beta-agonist

\section{TABLE 4}

\section{Asthma and career}

\begin{tabular}{lc}
\hline Response & $\mathbf{n}(\%)$ \\
\hline $\begin{array}{l}\text { Knows occupations that can worsen asthma (eg, animal } \\
\text { handlers, bakers, and resin, wood and metal workers) }\end{array}$ & $57(56.4)$ \\
Discussed asthma and future career with*: & \\
Parents & $44(43.6)$ \\
Friends & $30(29.7)$ \\
Girlfriend/boyfriend & $21(20.8)$ \\
Other family members & $18(17.8)$ \\
Family physician & $14(13.9)$ \\
Employer & $8(7.9)$ \\
Guidance counsellor & $5(5.0)$ \\
\hline
\end{tabular}

*Question asked participants to check all that apply; therefore, sum may not equal $100 \%$

the future were more likely to agree that asthma was an important factor in their future career plans $(\mathrm{P}=0.050)$.

Table 3 highlights the medical management and health care providers of participants. The majority of participants relied on primary care providers for their asthma management (91.1\%) and had never visited the emergency department for asthma (61.4\%). A direct relationship was observed between duration of asthma and ever visiting the emergency department for asthma $(\mathrm{P}=0.03)$. Most participants had never been hospitalized for asthma $(73.3 \%)$, but those that had been were significantly more likely to be followed by a respirologist or allergist $(\mathrm{P}<0.001$ and $\mathrm{P}=0.005$, respectively).

Responses to questions reflecting asthma control indicated that one-half of participants were awoken by asthma symptoms and $59.4 \%$ were symptomatic in the morning. At least some activity limitation was reported by $52.5 \%$ of participants and $60.4 \%$ reported mild to moderate dyspnea on a regular basis. However, a majority of participants $(55.4 \%)$ reported that they did not require the use of rescue short-acting beta-agonist inhalers.

Table 4 highlights participants' awareness of occupations that can exacerbate asthma and individuals with whom they have discussed asthma and their career plans. Most participants 
TABLE 5

Correlation analysis of sociodemographic variables and perception of asthma on career choice

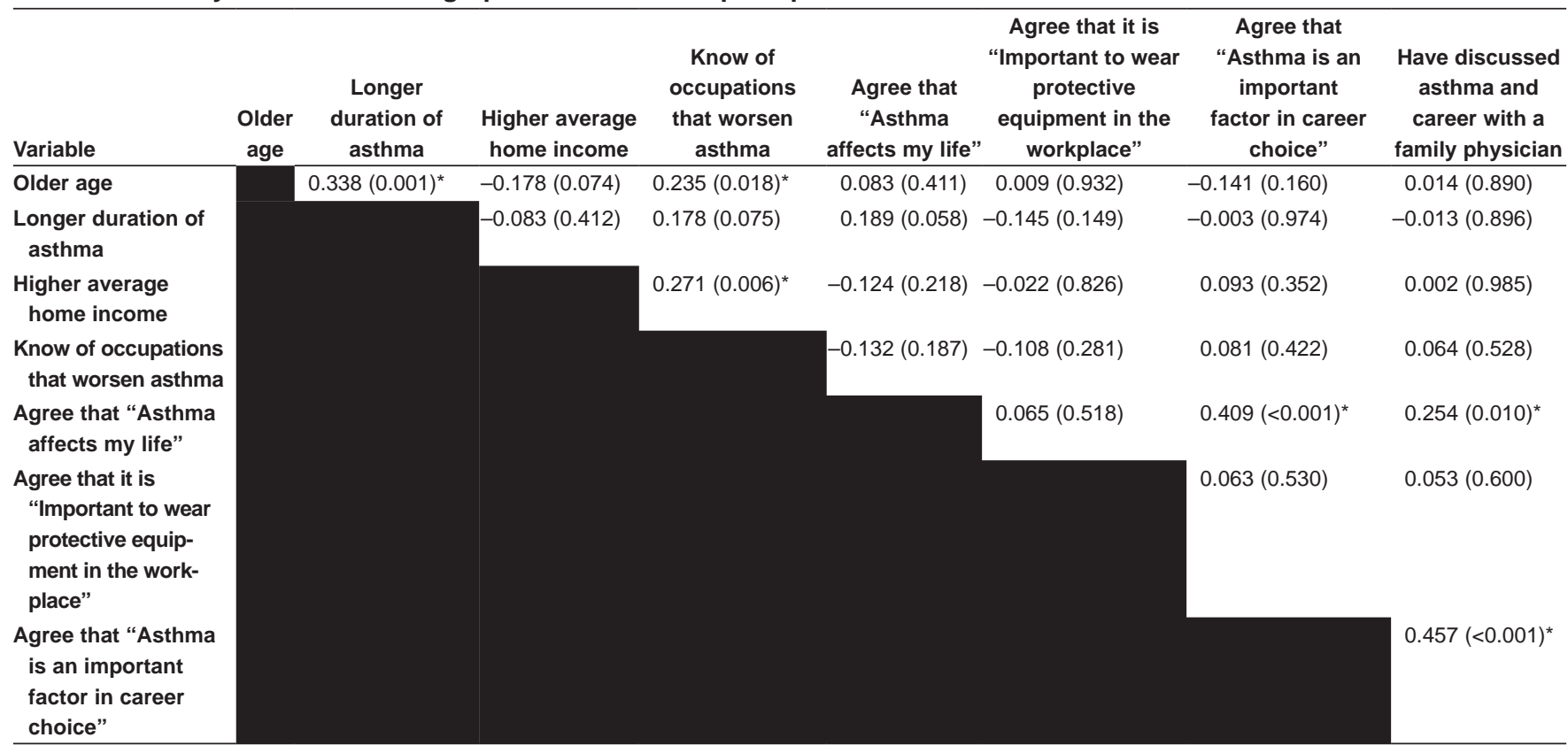

Data presented as Pearson correlation coefficient, $r(P)$. ${ }^{\star}$ Statistical significance set at $P<0.05$

discussed asthma and their career plans with family and friends but only a minority had this type of discussion with their family physician. Individuals that discussed their asthma and career plans with their family physician were more likely to report limitations in daily activities because of asthma $(\mathrm{P}=0.021)$, and agree that asthma affects their life and future career plans $(\mathrm{P}=0.010$ and $\mathrm{P}<0.001$, respectively).

Table 5 highlights correlations between sociodemographic variables and awareness of occupations that can worsen asthma and perception of asthma on career choice. Close to one-half (43.6\%) of participants could not identify occupations that could potentially aggravate asthma. Participants were more likely to be aware of occupations that could exacerbate asthma if they were older $(\mathrm{P}=0.018)$, lived in a higher income household $(\mathrm{P}=0.006)$, or had poor asthma control and frequent symptoms $(\mathrm{P}<0.05)$. The number of years lived with asthma approached statistical significance with escalating awareness of occupations that could exacerbate asthma ( $\mathrm{P}=0.075)$.

Logistic regression analysis indicated that higher average home income, a university education and older age were significant, independent predictors for reporting knowledge of occupations that could aggravate asthma $(\mathrm{P}<0.05)$. No significant, independent predictors were identified for discussing asthma and career plans with a physician.

\section{DISCUSSION}

Within our cohort, only a minority of participants agreed that asthma affected their life, although varying degrees of activity limitation was reported by $52.5 \%$ of participants and $60.4 \%$ had symptoms on awakening. Participants were recruited from community settings rather than from clinic or specialty clinic settings and are, therefore, likely to be more inclusive of milder asthmatic patients or those who do not seek regular medical care. Perhaps also reflecting mild and/or wellcontrolled asthma, the majority did not believe that asthma was an important factor in their career plans. However, this observation could also relate to adapting to and accommodating asthma symptoms. However, a substantial proportion (43\%) were not aware of occupations that can worsen asthma. Participants were unlikely to discuss asthma and their career plans with family physicians but typically held these conversations with their parents and/or friends. Potentially, these young asthmatic patients might have a higher risk of WEA if they are not aware of their increased susceptibility to WRA symptoms on exposure to dusts, fumes, sprays, exertion and temperature changes at work, and if they are not counselled as to the appropriate protective measures to take, such as the importance of appropriate respirators and maintenance of appropriate pharmacological therapy.

The present study noted that poor asthma control was associated with increased awareness of occupations that can exacerbate asthma, perhaps due to the need for greater interaction with health care professionals among subjects whose asthma was more difficult to control. Individuals with preexisting severe or poorly controlled asthma may experience a higher rate of work-related exacerbations when entering a work environment; however, to our knowledge, this has not been addressed in the literature.

Participants who desired a higher-ranking occupation in the future were more likely to agree that asthma was important in their career plans. Logistic regression analysis identified higher average home income, a university education and older age as significant independent predictors for reporting knowledge of occupations that can worsen asthma. These factors may reflect better education in general, and may suggest differences in awareness according to varying socioeconomic and demographic characteristics. These differences are likely important when developing educational materials/tools and identifying target populations at greater risk of, or entering workplaces at high risk for, exacerbating asthma. 
Our cohort included subjects from high school students through to recent university graduates, who were in career planning stages as well as a wide range of asthma duration and severity. However, most of our participants were university students, had above-average household incomes, aspirations for executive or professional future occupations, and relatively well-controlled asthma. Given the relatively 'advantaged' position of the present cohort, assessment of asthma knowledge can be regarded as a best-case scenario for awareness of asthma as a factor in career choice. It is possible that awareness may be lower for less advantaged adolescents.

For young adults with asthma, development of WRA could have profound personal and familial occupational and economic impact (21). If young adults with asthma are unaware of occupational risks and are reluctant to discuss the impact of asthma on their career with their asthma care provider, the window of opportunity to have an open dialogue and encourage thoughtful career planning is severely limited. Therefore, an educational intervention at this time may potentially be beneficial.

The main limitation of the present study was the relatively small sample size. A community-based approach to sample selection was used to capture the continuum of asthma severity and to avoid skewing the sample to reflect individuals with more severe asthma or those receiving specialist care. While a larger sample would have been desirable, our recruitment continued for more than a year, with numerous flyers and posters. The relatively small number of study volunteers may also be reflective of a lack of interest among this age group to consider the impact of asthma in their lives. While adolescence is generally not a time when asthmatic individuals seek significant asthma-related medical care or experience WRA, the self-referral process may have been more likely to select for individuals conscious of the relationship between asthma and their career.

Nevertheless, to our knowledge, this is the largest sample size that has been used to address the role of asthma as a factor in career choice among young adults with asthma.

ACKNOWLEDGEMENTS: The authors thank thank Sarah Alley and Sameer Agnihotri for their invaluable assistance in statistical analysis. They also thank Shelagh Finlayson and Ritu Makkar for their contributions to developing this study.

COMPETING INTEREST STATEMENT: Lisa Cicutto has received consulting funds from GlaxoSmithKline and AstraZeneca. All remaining authors have no competing interests to declare. Funded by the Ontario Ministry of Health and Long-Term Care.

\section{APPENDIX A: QUESTIONNAIRE}

\section{Section I: About yourself}

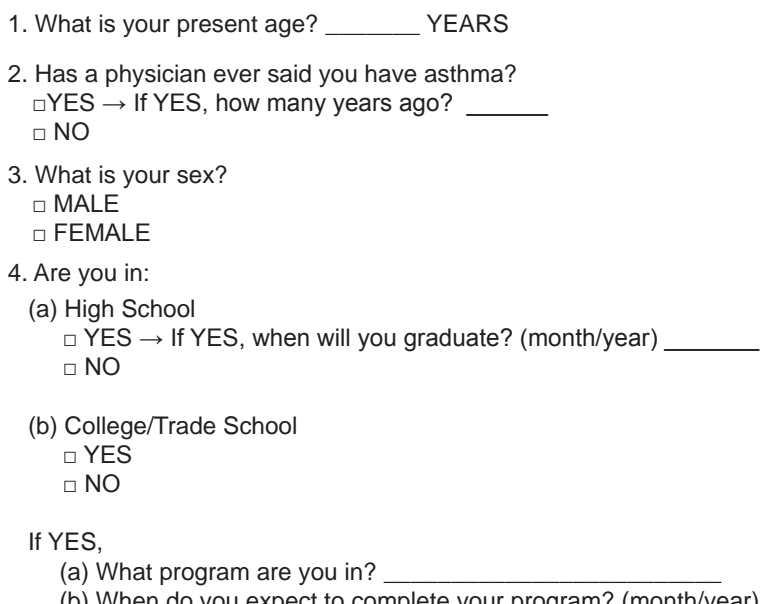

(c) University

$\square$ YES

$\square \mathrm{NO}$

If YES,

(a) What program are you in?

(b) When do you expect to complete your program? (month/year)

5. Are you presently working (paid or unpaid) in a workplace environment? $\square$ YES

$\square \mathrm{NO}$

If YES,

(a) What is your position title?

(b) What kind of company/business do you work for?

6. What are your parents'/guardians' occupations?

(If unemployed, write "unemployed". If not applicable, circle N/A)

口Parent/Guardian 1

$\square$ Parent/Guardian 2

7. What are the first 3 letters of your postal code?

\section{Section II: Your asthma}

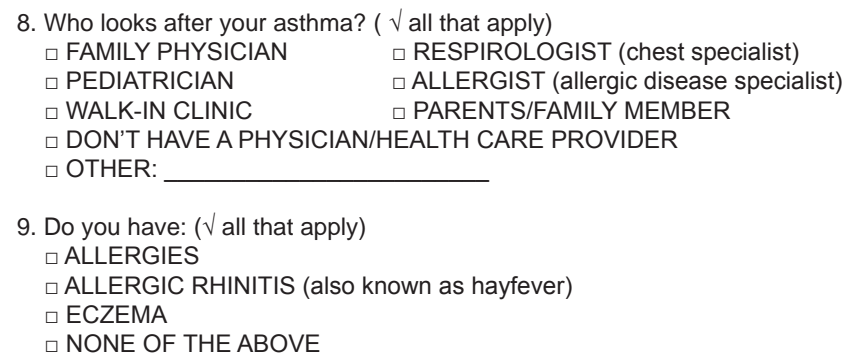

(a) If you have allergies, are they worse at different times of the year? $\square$ YES

$\square \mathrm{NO}$

(b) If YES, when are they the worst? ( $\sqrt{ }$ all that apply)

$\square$ SPRING MONTHS (April/May)

$\square$ SUMMER MONTHS (June/July)

$\square$ RAGWEED SEASON (mid-August to frost)

10. What things (triggers) make your asthma worse? ( $\sqrt{ }$ all that apply)

$\square$ FURRY ANIMALS (eg, dogs, cats) $\quad$ DUST

$\square$ OTHER ANIMALS: $\square$ MOULD

$\square$ AIR POLLUTION

$\square$ CIGARETTE SMOKE

$\square$ POLLEN

$\square$ RAGWEED

$\square$ FUMES (paint, ammonia, chlorine) $\square$ MEDICATIONS

$\square$ COLD AIR

$\square$ SCENTS

$\square$ COMMON COLDS

$\square$ FOOD

$\square$ EXCERCISE

$\square$ OTHER:

11. Do you presently smoke?

$\square$ YES

$\square \mathrm{NO}$

(a) If YES, how many cigarettes do you smoke per day?

$\square$ 0-10 $\square$ 11-20 $\square$ 21-30 $\square$ OVER 30

12. Does anybody smoke inside your home?

$\square$ YES

$\square \mathrm{NO}$ 
13. How many of your friends smoke around you?

$$
\square \text { NONE } \square \text { AFEW } \square \text { MOST } \square \text { ALL }
$$

14. Do you presently use any of the following medications for your asthma?

(a) Ventolin or Bricanyl (blue inhaler; reliever)

$\square$ YES $\rightarrow$ If YES, how many puffs do you use per day on average? $\square \mathrm{NO}$

(b) Flovent or Pulmicort (orange or white inhaler, with brown base ring) $\square$ YES $\rightarrow$ If YES, how many puffs do you use per day on average? $\square \mathrm{NO}$

(c) Serevent or Oxeze (aqua or white inhaler, with aqua base ring) $\square$ YES $\rightarrow$ If YES, how many puffs do you use per day on average? $\square \mathrm{NO}$

(d) Advair or Symbicort (purple or white inhaler, with red base ring) $\square$ YES $\rightarrow$ If YES, how many puffs do you use per day on average? $\square \mathrm{NO}$

(e) Singulair

$\square$ YES

$\square \mathrm{NO}$

(f) Prednisone

$\square$ YES

$\square$ NO

15. Have you ever gone to an emergency room because of your asthma? $\square$ YES $\rightarrow$ If YES, how many times in the past year? $\square \mathrm{NO}$

16. Have you ever been admitted to hospital for your asthma? $\square$ YES $\rightarrow$ If YES, how many times in the past year? $\square \mathrm{NO}$

\section{Section III: Your asthma control}

Circle the number of the response that best describes how you have been during the past week. (Circle only one option for each question)

17. On average, during the past week, how often were you woken by your asthma during the night?

0 NEVER

1 HARDLY EVER

2 AFEW TIMES

3 SEVERAL TIMES

4 MANY TIMES

6 UNABLE TO SLEEP BECAUSE OF ASTHMA

18. On average, during the past week, how bad were your asthma symptoms when you woke up in the morning?

\section{NO SYMPTOMS}

1 VERY MILD SYMPTOMS

2 MILD SYMPTOMS

3 MODERATE SYMPTOMS

4 QUITE SEVERE SYMPTOMS

5 SEVERE SYMPTOMS

6 VERY SEVERE SYMPTOMS

19. In general, during the past week, how limited were you in your activities because of your asthma?

0 NOT LIMITED AT ALL

1 VERY SLIGHTLY LIMITED

2 SLIGHTLY LIMITED

3 MODERATELY LIMITED

4 VERY LIMITED

5 EXTREMELY LIMITED

6 TOTALLY LIMITED

20. In general, during the past week, how much shortness of breath did you experience because of asthma?

0 NONE

1 A VERY LITTLE

2 A LITTLE

3 A MODERATE AMOUNT

4 QUITE A LOT

5 A GREAT DEAL

6 A VERY GREAT DEAL
21. In general, during the past week, how much of the time did you wheeze?

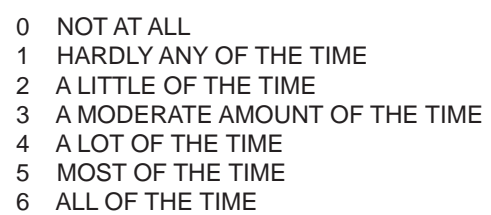

22. On average, during the past week, how many puffs of short-acting bronchodilator (blue reliever, i.e. Ventolin, Bricanyl) have you used each day?

0 NONE

1 1-2 PUFFS MOST DAYS

2 3-4 PUFFS MOST DAYS

3 5-8 PUFFS MOST DAYS

4 9-12 PUFFS MOST DAYS

5 13-16 PUFFS MOST DAYS

6 MORE THAN 16 PUFFS MOST DAYS

\section{Section IV: Asthma and your future}

23. What top 3 careers are you interested in pursuing in the future? 1.

2.

24. Do you know occupations that can make asthma worse (ie, trigger asthma episodes)?

$\square$ YES

$\square \mathrm{NO}$

(a) If YES, please give us some examples:

CIRCLE THE OPTION THAT CORRESPONDS MOST CLOSELY TO YOUR OPINION.

26. Asthma affects my daily life.
1 STRONGLY AGREE
2 AGREE
3 NEITHER AGREE NOR DISAGREE
4 DISAGREE
5 STRONGLY DISAGREE

27. It is important for people with asthma to use protective measures (eg, masks) in the workplace.

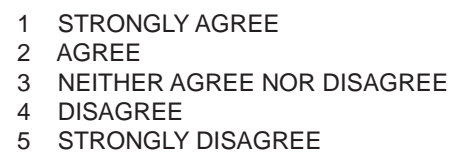

28. Asthma has been an important factor in my plans about my future career.

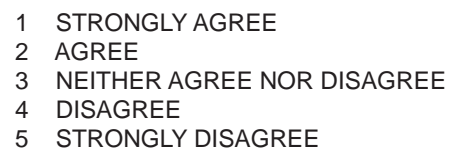

29. If asthma has played a role in your future career plans, please explain:

30. Have you had any discussions with your physician about asthma and your future career?

$\square$ YES

$\square \mathrm{NO}$

31. Have you talked with other people about asthma and your future career? ( $\sqrt{ }$ all that apply)

$\square$ OTHER HEALTH CARE PROVIDER $\square$ PRESENT EMPLOYER

$\square$ PARENTS

$\square$ OTHER FAMILY MEMBERS $\square$ GIRLFRIEND/BOYFRIEND 


\section{REFERENCES}

1. Centers for Disease Control and Prevention-National Center for Health Statistics. Asthma Fast Stats. Hyattsville, MD, 2007. $<$ http://www.cdc.gov/nchs/products/pubs/pubd/hestats/ashtma03-05/ asthma03-05.htm> (Version current at February 21, 2009).

2. Public Health Agency of Canada. Life and Breath: Respiratory Disease in Canada-Asthma. Ottawa, 2007. <http://www.phac-aspc. gc.ca/publicat/2007/lbrdc-vsmrc/pdf/PHAC-Respiratory-WEB-eng. pdf $>$ (Version current at February 21, 2009).

3. Strachan DP, Anderson HR, Limb ES, O'Neill A, Wells N. A national survey of asthma prevalence, severity, and treatment in Great Britain. Arch Dis Child 1994;70:174-8.

4. Buston KM, Wood SF. Non-compliance amongst adolescents with asthma: Listening to what they tell us about self-management. Fam Pract 2000;17:134-8.

5. Cochrane GM. Therapeutic compliance in asthma; its magnitude and implications. Eur Respir J 1992;5:122-4.

6. de Benedictis D, Bush A. The challenge of asthma in adolescence. Pediatr Pulmonol 2007;42:683-92.

7. Hendrick DJ. The world wide problem of occupational asthma. Clin Exp Allergy 2001;31:1-4.

8. Henneberger PK. Work-exacerbated asthma. Curr Opin Allergy Clin Immunol 2007;7:146-51.

9. Cullinan P, Tarlo S, Nemery B. The prevention of occupational asthma. Eur Respir J 2003;22:853-60.

10. Selgrade MK, Lemanske RF Jr, Gilmour MI, et al. Induction of asthma and the environment: What we know and need to know. Environ Health Perspect 2006;114:615-9.

11. Wiebert P, Svartengren M, Lindberg M, Hemmingsson T, Lundberg I, Nise G. Mortality, morbidity and occupational exposure to airway-irritating agents among men with a respiratory diagnosis in adolescence. Occup Environ Med 2008;65:120-25.

12. Martin AJ, Landau LI, Phelan PD. Asthma from childhood at age 21: The patient and his disease. Br Med J (Clin Res Ed) 1982;284:380-2.

13. Radon K, Huemmer S, Dressel H, et al. Do respiratory symptoms predict job choices in teenagers? Eur Respir J 2006;27:774-8.

14. Dillman DA. Mail and Telephone Surveys. In: The Total Design Method, 1st edn. New York: John Wiley and Sons, 1978: Chapters 2-4.

15. Boulet LP, Becker A, Berube D, Beveridge R, Ernst P. Canadian Asthma Consensus Report, 1999. Canadian Asthma Consensus Group. CMAJ 1999;161(11 Suppl):S1-61.

16. Juniper EF, O'Byrne PM, Guyatt GH, Ferrie PJ, King DR. Development and validation of a questionnaire to measure asthma control. Eur Respir J 1999;14:902-7.

17. Hollingshead AB. Two-Factor Index of Social Position, 1st edn. New Haven: Privately Printed, Yale Station, 1965:351-9.

18. Myers JK, Bean LL. A Decade Later: A Follow-up of Social Class and Mental Illness. 1st edn. New York: John Wiley and Sons, 1968.

19. Ritsher JE, Warner V, Johnson JG, Dohrenwend BP. Intergenerational longitudinal study of social class and depression: A test of social causation and social selection models. Br J Psychiatry 2001(Suppl 40):s84-90.

20. Statistics Canada. Income of individuals, families and households (20\% sample data) forward sortation areas. Customized Database Query: Basic cross-tabulations: Catalogue Number 95F0437XCB2001005-fsa, Released May 2003. <http://www.statcan. gc.ca/bsolc/olc-cel/olc-cel?catno=95F0437XCB2001005\&lang=eng > (Version current at February 21, 2009).

21. Vandenplas O, Toren K, Blanc PD. Health and socioeconomic impact of work-related asthma. Eur Respir J 2003;22:689-97. 


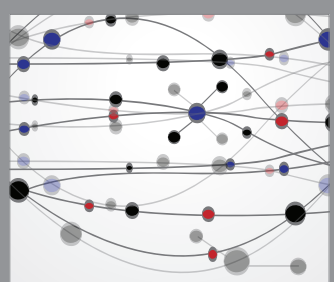

The Scientific World Journal
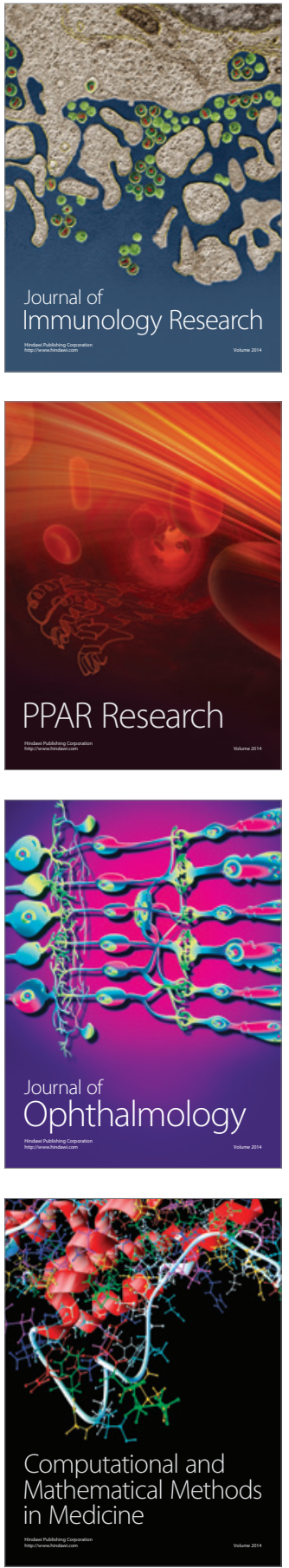

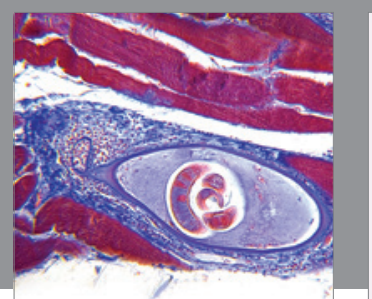

Gastroenterology Research and Practice

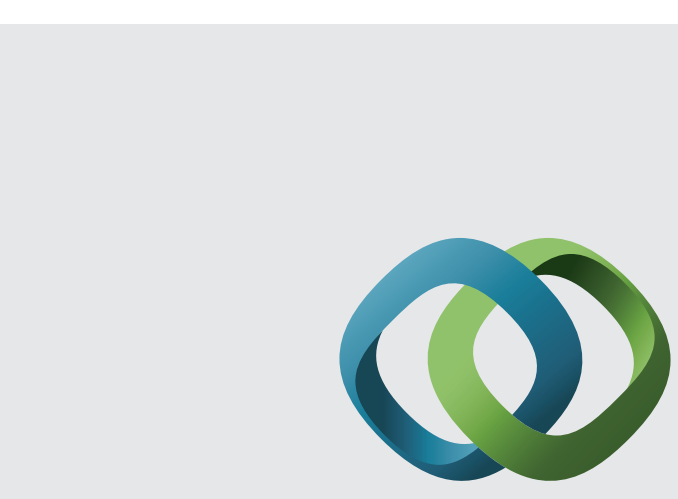

\section{Hindawi}

Submit your manuscripts at

http://www.hindawi.com
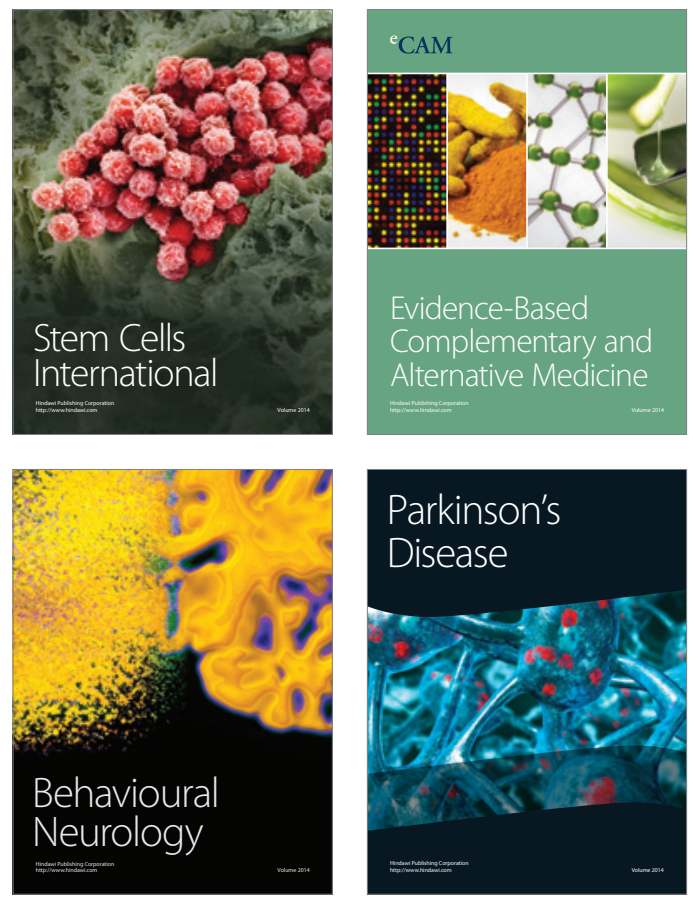
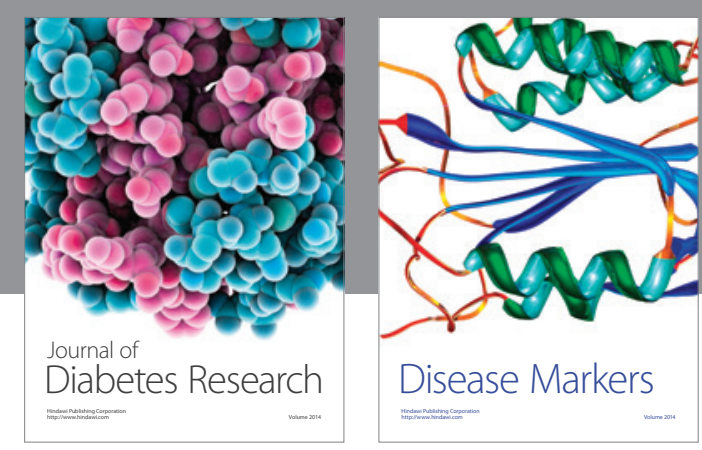

Disease Markers
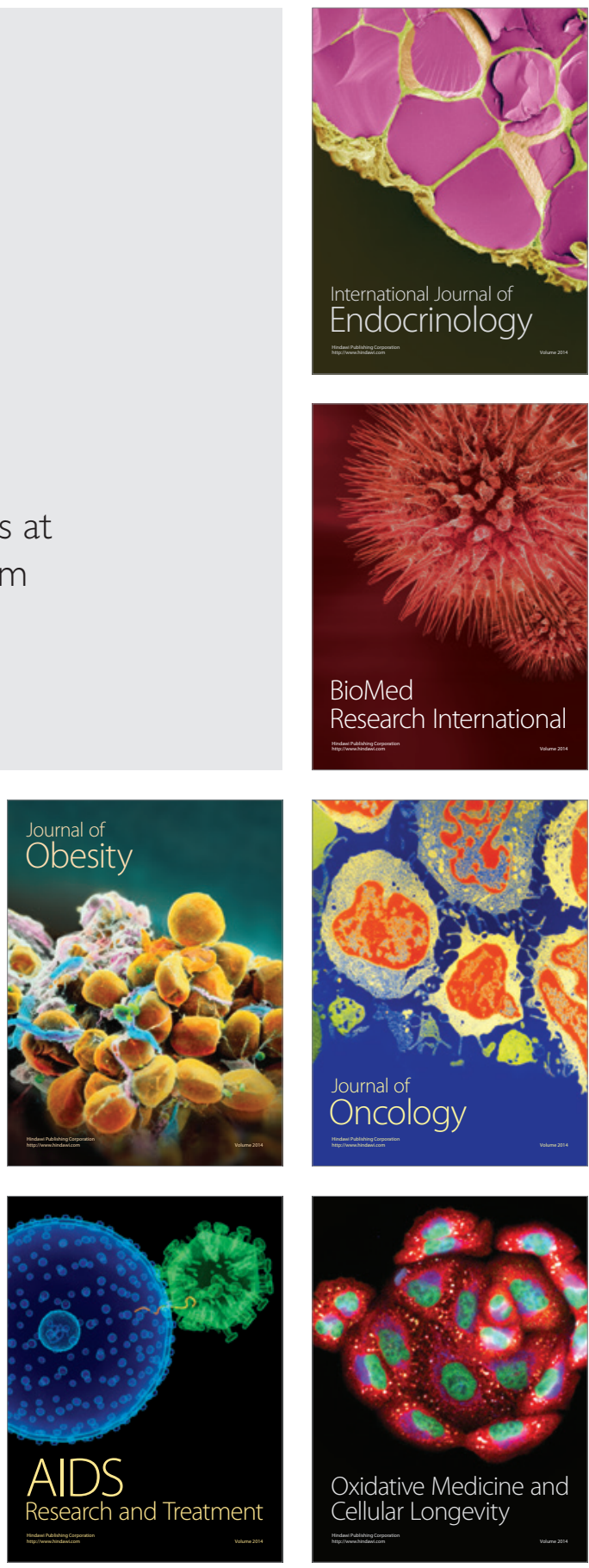